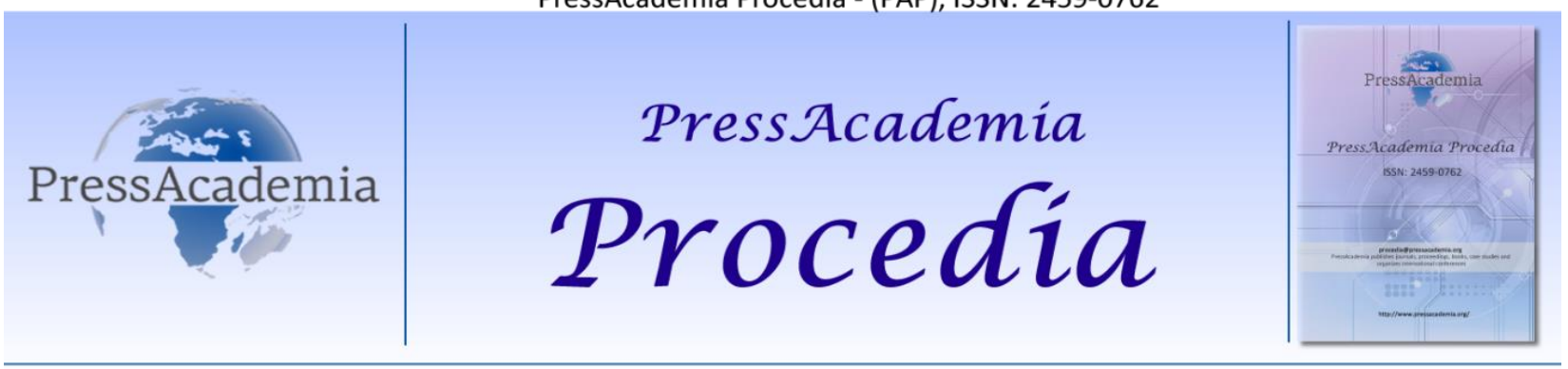

2nd World Conference on Technology, Innovation and Entrepreneurship

May 12-14, 2017, Istanbul, Turkey. Edited by Sefer Şener

\title{
REVIEW OF THE PRACTICE OF PORTER'S GENERAL COMPETITIVE STRATEGIES IN CAR RENTAL ENTERPRISES
}

\author{
DOI: 10.17261/Pressacademia.2017.554 \\ PAP-WCTIE-V.4-2017(46)-p.349-356
}

\section{Bayram Akay}

Kırklareli University, Faculty of Tourism, Travel Management and Tourism Guidance, bayramakay@klu.edu.tr

\begin{abstract}
The purpose of this study is to examine the practices of Porter's general competitive strategies (cost leadership, differentiation, focusing and stuck in the middle) on car rental enterprises in Turkey and to contribute to future studies. The data has been obtained from 200 car rental enterprises operating in İstanbul and Antalya in the research. As a result of the research, it has been revealed that the enterprises apply differentiation, cost leadership and focusing respectively among the competitive strategies and there are also enterprises that are trapped between them without choosing any of these strategies. In addition, a difference has been found between the managers' gender, marital status, mission, level of education, educational field, number of branches of the business, number of vehicles and perception of competition strategies. It can be suggested that car rental enterprises will be successful if they implement competitive strategies.
\end{abstract}

Keywords: Tourism, car rental, competitive strategies.

JEL Codes: G10, G32

\section{INTRODUCTION}

The car rental sector provides billions of dollars of income to the economy of many countries. For example, in the US with 2.3 million rental cars capacity in 2016, the car renter sector's contribution to the economy was about $\$ 28.4$ billion (www.autorentalnews.com). In the world, the car rental industry is most prevalent in the US, Europe and other developed countries. The sector is also growing in developing countries such as India, China and Brazil (Tyya, 2007: 112). In Turkey, car rental companies operating in airports and big city centers in the past years provides services in many tourism regions as a result of rapid developments in the tourism sector (MEB, 2007: 55). In Turkey, 6-7\% of the operational rentals are made by the public, although there is no clear data regarding the sector's operational and daily rental market. The market share of the top 10 largest firms in Turkey is $69 \%$ and the remaining $31 \%$ is shared by hundreds of various-sized firms (Karaboğa, 2012: 2). In the car rental sector, istanbul takes the first place with 70\% share, followed by Ankara at the second izmir at the third. However, in summer, the trend reverses and there is a shift towards tourism centers such as Antalya, Muğla and Aydın (www.turizmgazetesi.com).

The car rental sector in Turkey, along with tourism and business activities, has shown significant improvement due to the increase in the middle-class population with high disposable income, and the acceleration of the infrastructure investments by the government. Turkey's favorable economic environment has made the country an attractive destination for car rental operators. Turkish car rental sector grew by $8.21 \%$ in $2007-2011$ period and reached $\$ 3.3$ billion in 2011 . The sector is expected to grow rapidly, reaching 5.4 billion dollars in 2016 and growing by $10.11 \%$ over this period (Market Publishers Report Database, 2012: 55). The car rental industry has a very competitive structure. The sector is shaped by intense price and service competition. Competition is primarily based on other factors such as price, reliability, vehicle status, national distribution, availability of reservation systems, renting and returning convenience and customer service. Competition in the car rental sector is strongly influenced by advertisement, marketing and brand reputation (Datamonitor, 2011:7), other transportation systems such as planes and taxis (Marijanovic, 2010: 113), fuel and plane ticket prices, vehicle size and type (Mancini, 2012: 175).

In the tourism literature, there is almost no focus on rent-a-car establishments (Marijanovic, 2010), while there is a considerable interest in topics such as hotels, food and beverage or gastronomy, tour operators, railways, roads and 
destination management. Again, there is little emphasis on competition strategies in tourism literature (Enright \& Newton, 2004; Llo, 2012; Garcia et al., 2016). In this study, the competition strategies of car rental companies (cost leadership, differentiation, focusing and stuck in the middle) will be emphasized and information about competition in car rental companies will be provided. The paper is organized as follows. Section 2 describes conceptial framework. Section 3 describes research metodology, Section 4 reports and discusses the empirical findings. And the final section gives conclusions and assetments.

\section{CONCEPTUAL FRAMEWORK}

In general, the car rental sector is divided into three market segments: travel, financial leasing and replacement car market. In this case, it can be regarded as TOURISM + BUSINESS + LOCAL market (Geraghty and Johnson, 1997: 109). A number of international car rental giants in the sector including Europcar, Hertz, Avis Budget, Sixt, Alamo, Zipcar, Dollar and Enterprise, as well as many local enterprises are operating in the region (Yang et al., 2009: 1202). The car rental sector takes place in two forms: long-term car rentals (more than 12 months) and short-term car rentals (hourly/daily /monthly). Long-term car rental activities are mainly divided into operational renting and financial renting. Short-term car rental activities take place in two forms: daily car rental and one-year minimum rental (Gençler, 2012). In operational renting, the rental company undertakes all variable and fixed costs such as maintenance, repair, insurance, tax and service follow-up (Kesenci, 2010: 83). In the financial leasing method, while the ownership of the vehicles is in the leasing company, costs such as maintenance, repair and depreciation expenses of the vehicles are undertaken by the leasing customer (Gezer ve Çiçek, 2011: 175). The renting customer is responsible for all costs incurred during the use of the vehicle (fuel, accident, breakdown, bridge and highway crossings, traffic fines, etc.). Competition is the entirety of activities to gain superiority and to surpass the competitors (Funk et al., 2009: 45). Competition, according to the law on the protection of competition no. 4054, is a race that allows free economic decisions to be made among the enterprises in the goods and services markets. The competitive strategy is analyzing the sector or industry in which an operator is involved from a competitive point of view; then the things done or intended to be done to achieve competitive advantage against the competitors in the industry and thus achieve the business goals (Porter, 2000).

\subsection{Cost Leadership Strategy}

Cost leadership requires the establishment of operational facilities with efficient scale, obtaining strong cost reductions from experience, strict cost and overhead control, avoiding small client accounts, and the reduction of costs in areas such as R\&D, service, sales force and advertisement (Porter, 2000: 44). By creating a cost advantage in this way, it is possible to increase the number of customers and hence the market share via shifting towards a wider market (Bahar and Kozak, 2012: 98). The business sense of the companies in the car rental sector can be divided into groups according to these competition strategies. For example, companies operating outside the airport follow the cost leadership principle. To maintain this strategy, businesses need to reduce costs, overhead, R \& D, the service sales force and advertising costs and require strict cost control. In fact, although all companies pay the same price for their vehicles, businesses operating outside the airport can rent cars at low prices (Pachon, 2000: 65).

\subsection{Differentiation Strategy}

The differentiation strategy is the ability to offer a unique product or service. By differentiating the product or service offered by the business, the business will be in a more advantageous position compared to the products, technologies, images and services offered by its competitors in all sectors (Aktan and Vural, 2004: 47). The businesses that anticipate the changes in the customer profile and requests in due time and determine the appropriate differentiation will further increase their market share by preserving their competitive position (Bahar and Kozak, 2012: 98). In the differentiation, brand loyalty of the customer is created and the price sensitivity decreases. In the maturing car rental sector, the eligibility necessary for high-priced service differentiation is not clear (Pachon, 2000: 65).

\subsection{Focusing Strategy}

The focusing strategy is to focus on a specific buyer group, a segment of the product range or geographical market. The business that achieves the focus can potentially earn above the sector average (Porter, 2000: 48). In focusing, it is important to identify the areas where the service providers in the sector place less emphasis or where the customer requests are not adequately responded to (Bahar \& Kozak, 2012: 98). In the car rental industry, Enterprise has specialized in insurance. Applications such as nostalgic, limousine, hourly car rental are the focus of the car rental business (Pachon, 2000: 66). 


\subsection{Stuck in the Middle}

Porter describes the businesses that are not in included any group among cost leadership, differentiation and focusing as "stuck in the middle" between the three generic competitive strategies. If the company fails to develop one of the three strategic behaviors mentioned above, it will have a fuzzy organizational culture and conflicting organizational arrangements (Cronshaw et al., 1994: 20). These businesses almost guarantee low profitability. Either they lose high volume customers who demand low prices or they have to give up their profits to get the business from low cost enterprises (Porter, 200: 52).

\section{RESEARCH METHODOLOGY}

\subsection{Method of the Research}

The data of the research were obtained from the managers of the car rental companies in istanbul and Antalya via questionnaire technique. The questionnaire includes questions that measure demographic questions and competitive strategies (cost leadership, service differentiation, focus and stuck in the middle). The 15 questions that measure the level of implementation of the companies' competitive strategies were taken from Türkay (2007) and Taşkın et al., (2011). All questions were measured using the 5-point Likert scale. The research was conducted in person and online with car rental managers in İstanbul and Antalya between January and October of 2016. Convenience sampling method, one of the nonrandom sampling methods, was preferred in the research (Altunışık et al., 2005: 132). Each vehicle rental business responding to the survey was included in the sample. A total of 200 people was reached and since no missing data was found, all questionnaires were included in the analysis.

\subsection{The Purpose and Importance of the Research}

The purpose of this research is to review the implementation of general competition strategies in Turkey's car rental businesses and to contribute to further studies. The research is important in terms of providing a general overview of sector with regard to competition by assessing car rental businesses in terms of competition strategies, and helping future businesses to select competitive strategies.

\subsection{Analyses of the Research Data and Hypotheses}

In the research; frequency, reliability, t-test and ANOVA analyzes were performed with SPSS (22.0) packet program. For normal distribution, it is sufficient to look at only one or both of the skewness and kurtosis values (Kline, 2011). It is expected that the skewness and kurtosis values are \pm 2.58 for the $5 \%$ confidence interval and the statistic value range is \pm 1.96 for the 1\% confidence interval (Yucenur et al., 2011). As the skewness and kurtosis values of the research are between 0.216 and 1.782 , it is exhibited that the data is in conformity with normal distribution. Since the data is distributed normally, parametric analysis techniques have been used. The research hypotheses have been established as follows.

- $\mathrm{H}_{1}$ : There is a difference between the genders of the managers and their competition strategy applications.

- $\mathrm{H}_{2}$ : There is a difference between the marital status of the managers and their competition strategy applications.

- $\mathrm{H}_{3}$ : There is a difference between the competition strategy applications of the managers and the number of branches.

- $\mathrm{H}_{4}$ : There is a difference between the competition strategy applications of the managers and the number of vehicles.

- $\mathrm{H}_{5}$ : There is a difference between the education level of the managers and their competition strategy applications.

- $\mathrm{H}_{6}$ : There is a difference between the expertise of the managers and their competition strategy applications.

- $\mathrm{H}_{7}$ : There is a difference between the duties of the managers and their competition strategy applications.

\section{FINDINGS OF THE RESEARCH}

Table 1 shows the demographic and business characteristics obtained from the findings and Table 2 shows the generic competition strategies of the businesses. 
Table 1: Demographic and Business Characteristics

\begin{tabular}{|c|c|c|c|c|c|}
\hline Gender & Frequency & Percent & Marital Status & Frequency & Percent \\
\hline Male & 181 & 90,5 & Married & 115 & 57,5 \\
\hline Female & 19 & 9,5 & Single & 85 & 42,5 \\
\hline Total & 200 & 100,0 & Total & 200 & 100,0 \\
\hline Position & Frequency & Percent & Target Market & Frequency & Percent \\
\hline Senior Manager & 113 & 56,5 & Daily Rental & 50 & 25,0 \\
\hline $\begin{array}{l}\text { Midd. Level } \\
\text { Manager }\end{array}$ & 54 & 27,0 & Operating lease & 9 & 4,5 \\
\hline First Line Manager & 33 & 16,5 & Both of them & 141 & 70,5 \\
\hline Total & 200 & 100,0 & Total & 200 & 100,0 \\
\hline Educational Status & Frequency & Percent & Educational Field & Frequency & Percent \\
\hline Primary (8 years) & 18 & 9,0 & Tourism & 21 & 10,5 \\
\hline High School & 66 & 33,0 & Business & 41 & 20,5 \\
\hline Associate Degree & 77 & 38,5 & Economy & 15 & 7,5 \\
\hline Bachelor's Degree & 29 & 14,5 & Automotive & 17 & 8,5 \\
\hline Master's Degree & 10 & 5,0 & Other & 106 & 53,0 \\
\hline Total & 200 & 100,0 & Total & 200 & 100,0 \\
\hline Number of Cars & Frequency & Percent & $\begin{array}{ll}\text { Number of } \\
\text { Branches }\end{array}$ & Frequency & Percent \\
\hline Between 3-17 & 43 & 21,5 & Between 0-1 & 99 & 49,5 \\
\hline Between 18-31 & 53 & 26,5 & Between 2-90 & 110 & 50,5 \\
\hline Between 32-72 & 52 & 26,0 & & & \\
\hline Between 73-25.000 & 25 & 26,0 & & & \\
\hline Total & 200 & 100,0 & Total & 200 & 100,0 \\
\hline
\end{tabular}

Table 1 exhibits that the majority of the managers participating in the research are male (90.5\%) and senior managers (56.5\%). 57.5\% of the managers are married and $42.5 \%$ are single. Businesses prefer both daily and operational renting (70.5\%) among market segments. 38,5\% of the managers have associate degree, $33,0 \%$ are high school graduates and $14,5 \%$ are undergraduates. It can be said that the car rental sector in Turkey is managed by well-trained managers. In businesses, tourism graduates account for only $10.5 \%$. Besides, the ratio of business graduates is $20,5 \%$, automotive $8,5 \%$, economy $7,5 \%$ and percentage of the individuals marking the option 'other' is $53 \%$. Other graduated fields are sociology, philosophy, history, geography, foreign trade, graphic design, computer, public administration, finance, public relations, construction-machinery and electronics engineering. Despite being a tourism activity, it is observed that the areas where the managers take education are different. It is noted that $21.5 \%(43)$ of the vehicle rental companies operating in istanbul and Antalya have between 3 and 17 vehicles, 26.5\% (53) have between 18 and 31 vehicles, $26.0 \%$ (52) have between 32 and 73 and $72 \%$ and $26 \%$ (52) have between 73 and 125 respectively. It is also observed that $49.5 \%$ (99) of these enterprises have $0-1$ branches and $50.5 \%$ (101) of them have 2-90 branches in terms of the number of branches.

Table 2: Generation Competition Strategies and Performance Averages of Businesses

\begin{tabular}{lcc}
\hline Statements & Mean & Std. D. \\
\hline Differentiation & 4.12 &, 869 \\
The ability of the business to create different services & 4,17 &, 907 \\
The level of defining the target market clearly & 4,12 &, 825 \\
The level of providing service defined based on the target market & 4,19 &, 909 \\
The level of providing personalized service & 4,30 &, 739 \\
\hline Cost Leadership & 4,31 &, 833 \\
The level of capacity usage (Occupancy ratio) & 3,99 & 1,112 \\
Your efficiency level in the activities & 3,72 &, 922 \\
Your level to offer competitive prices & 4,06 &, 02 \\
Emphasizing on the efforts to decrease the costs & & \\
\hline
\end{tabular}




\begin{tabular}{lcc}
\hline Focusing & $\mathbf{3 . 9 6}$ & \\
The efficiency of distribution channels (agency, the Internet, merchant etc.) & 3,73 & 1,283 \\
The capability to offer various product choices & 4,02 & 1,121 \\
The capability to address different types of clients & 4,18 &, 891 \\
The level of operating on different markets & 3,90 & 1,134 \\
\hline Stuck in the Middle (Strategic Indecision) & $\mathbf{3 . 8 6}$ & \\
Creating close connections between the departments of the business & 4,03 & 1,107 \\
Monitoring the competitors' behavior & 3,85 & 1,118 \\
Spending money for promotion and advertisement over the sector average & 3,71 & 1,278 \\
\hline Cronbach Alfa = ,91 & & \\
(Note: 5-point likert scale 1: Very Low, 2: Low, 3: Slightly Low, 4: High, 5: Very High) & & \\
\hline
\end{tabular}

Table 2 indicates the arithmetic mean and standard deviation values of the competitive strategies applied by the participating businesses. When this table is examined, it can be observed that the most intensive competition strategies are "differentiation", "cost leadership", "focus" and "stuck in the middle", respectively. The managers have defined the ability to produce different services (Avg. 4,17), the level of defining the target market clearly (Avg. 4,12), the level of service presentation defined according to the target market $($ Ort 4,19$)$ and the level of offering personalized services (Avg. 4.30) as high. That is, businesses operating in istanbul and Antalya implement the diversification strategy at a significant level. For the cost leadership strategy, managers have stated that level of capacity utilization (occupancy rate) (Avg. 4,31), the activity levels in the operations (Avg. 3.99), the level of offering competitive prices (Avg. 3,72) and the level of emphasizing the cost reduction efforts (Avg. 4.06). In this case, it can be said that car rental companies give importance to cost leadership strategy. Managers are highly involved in the focusing strategy, which means providing services to a specific buyer group or to a geographically small area. Within this scope, it can be observed that the levels of efficiency of the businesses' distribution channels (agency, internet, dealers etc.), (Avg. 3,73), the capability to offer various product options (Avg. 4,02), addressing different customer types (Avg. 4,18) and ability to operate in different markets (Avg 3.90) are high. Services are provided to special buyer group or smaller geographical areas. The businesses that are not in included any group among cost leadership, differentiation and focusing are defined as "stuck in the middle" between the three generic competitive strategies. The level of creating close connections (Avg. 4,03) between departments, monitoring the behavior of the competitors (Avg. 3,83) and spending money on promotion and advertisement over the sector average (Avg. 3,72 ) is very high for the businesses falling in this group. This shows that the business operating in istanbul and Antalya are the ones that have not been able to apply any of the three general competition strategies and are trapped between them.

\subsection{Hypothesis Tests Results}

The results of the analysis of the differences between managers' gender, marital status, mission, level of education, educational field, number of branches of the business, number of vehicles and perception of competition strategies are shown below.

Table 3: The Relationship Between the Competition Strategies and Gender (t-Test).

\begin{tabular}{|c|c|c|c|c|c|c|}
\hline Competition Strategies & Gender & $\mathbf{n}$ & Mean & S.D. & $f$ & $p$ \\
\hline \multirow[t]{2}{*}{ Differentiation } & Male & 181 & 13,62 & 2,40 & \multirow{2}{*}{ 118 } & \multirow{2}{*}{,731 } \\
\hline & Female & 19 & 13,00 & 2,23 & & \\
\hline \multirow[t]{2}{*}{ Cost Leadership } & Male & 181 & 13,11 & 1,96 & \multirow{2}{*}{6,796} & \multirow{2}{*}{010} \\
\hline & Female & 19 & 12,32 & 2,95 & & \\
\hline \multirow[t]{2}{*}{ Focus } & Male & 181 & 12,93 & 2,83 & \multirow{2}{*}{3,415} & \multirow{2}{*}{,066 } \\
\hline & Female & 19 & 12,65 & 3,87 & & \\
\hline \multirow[t]{2}{*}{ Stuck in the middle } & Male & 181 & 9,16 & 2,13 & \multirow{2}{*}{, 126 } & \multirow{2}{*}{,723 } \\
\hline & Female & 19 & 8,73 & 2,60 & & \\
\hline
\end{tabular}

Table 3 exhibits whether there is a relationship between competition strategies and gender. There was no significant difference in the $p>0.05$ significance level between the competition strategies (differentiation, focus and stuck in the middle) that were included in the analysis and gender variable. There is a difference in the significance level of $p<0.05$ between the cost leadership and gender variable in competition strategies. In other words, male and female managers perceive only the strategy of cost leadership in between among the competition strategies in a different way while they 
perceive the others as the same. In this case, the $\mathrm{H}_{1}$ hypothesis is accepted for the cost leadership variable, while it is rejected for other variables.

Table 4: The Relationship Between the Competition Strategies and Marital Status (t-Test)

\begin{tabular}{|c|c|c|c|c|c|c|}
\hline Competition Strategies & Gender & 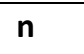 & Mean & S.D. & $f$ & $p$ \\
\hline \multirow[t]{2}{*}{ Differentiation } & Married & 115 & 13,63 & 2,27 & \multirow{2}{*}{,219 } & \multirow{2}{*}{ 641 } \\
\hline & Single & 85 & 13,47 & 2,56 & & \\
\hline \multirow[t]{2}{*}{ Cost Leadership } & Married & 115 & 13,11 & 2,00 & \multirow{2}{*}{,953 } & \multirow{2}{*}{,330 } \\
\hline & Single & 85 & 12,93 & 2,19 & & \\
\hline \multirow[t]{2}{*}{ Focus } & Married & 115 & 13,05 & 2,87 & \multirow{2}{*}{, 064} & \multirow{2}{*}{,801 } \\
\hline & Single & 85 & 12,71 & 3,02 & & \\
\hline \multirow[t]{2}{*}{ Stuck in the middle } & Married & 115 & 9,17 & 2,00 & \multirow{2}{*}{4,481} & \multirow{2}{*}{036} \\
\hline & Single & 19 & 8,73 & 2,60 & & \\
\hline
\end{tabular}

There was no significant difference at $p>0.05$ significance level between the competition strategies (differentiation, focus and stuck in the middle) that were included in the analysis in Table 4 and marital status variation. There is a difference at $\mathrm{p}<0.05$ significance level between stuck in the middle and marital status variation in competition strategies. In other words, single and married managers perceive only the strategy of stuck in the middle among the competition strategies in a different way while they perceive the others as the same. In this case, the $\mathrm{H}_{2}$ hypothesis is accepted for the cost leadership variable, while it is rejected for other variables.

Table 5: The Relationship Between the Competition Strategies and Number of Branches (t-Test)

\begin{tabular}{|c|c|c|c|c|c|c|}
\hline $\begin{array}{l}\text { Competition } \\
\text { Strategies }\end{array}$ & $\begin{array}{c}\text { Number of } \\
\text { Branches }\end{array}$ & $n$ & Mean & S.D. & f & p \\
\hline \multirow[t]{2}{*}{ Differentiation } & $0-1$ & 76 & 13,7 & 2,12 & \multirow{2}{*}{1,653} & \multirow{2}{*}{ 200 } \\
\hline & $2-90$ & 124 & 13,5 & 2,55 & & \\
\hline \multirow[t]{2}{*}{ Cost Leadership } & $0-1$ & 76 & 13,3 & 2,15 & \multirow{2}{*}{,636 } & \multirow{2}{*}{,426 } \\
\hline & $2-90$ & 124 & 12,9 & 2,03 & & \\
\hline \multirow[t]{2}{*}{ Focus } & $0-1$ & 76 & 13,6 & 2,70 & \multirow{2}{*}{3,588} & \multirow{2}{*}{,060 } \\
\hline & $2-90$ & 124 & 12,7 & 3,04 & & \\
\hline \multirow[t]{2}{*}{ Stuck in the middle } & $0-1$ & 76 & 9,5 & 1,92 & \multirow{2}{*}{4,486} & \multirow{2}{*}{, 032} \\
\hline & $2-90$ & 124 & 8,9 & 2,30 & & \\
\hline
\end{tabular}

The number of branches operated by the businesses in the research is categorized as 0-1, 49.5\% (99) and 2-90, 50.5\% (101). There was no significant difference at $p>0.05$ significance level between competition strategies (differentiation, cost leadership and focusing) and number of branches. There was no significant difference at $p<0.05$ significance level between stuck in the middle and the number of branches. That is, the number of branches of the business indicates difference only for the strategy of stuck in the middle among the competition strategies.

Table 6: The Relationship Between Competition Strategies with Number of Vehicles, Level of Education, Education Area and Duties (ANOVA Test)

\begin{tabular}{|c|c|c|c|c|c|c|}
\hline Variables & $\begin{array}{l}\text { Competition } \\
\text { Strategies }\end{array}$ & $f$ & $\mathbf{p}$ & Variables & $f$ & $p$ \\
\hline \multirow{4}{*}{ 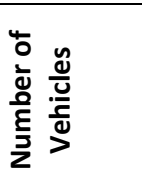 } & Differentiation & 3,686 & 013 & \multirow{4}{*}{ 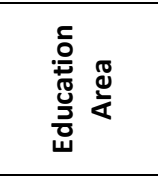 } & 1,588 & 179 \\
\hline & Cost Leadership & 2,806 & 041 & & 1,351 & 253 \\
\hline & Focus & 7,772 &, 003 & & ,812 & ,519 \\
\hline & Stuck in the middle & ,814 & ,488 & & 3,205 & $\underline{\underline{014}}$ \\
\hline \multirow{4}{*}{ 屯。 } & Differentiation & 194 & ,941 & \multirow{4}{*}{ 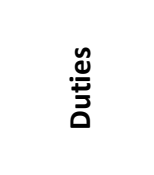 } & 811 & ,446 \\
\hline & Cost Leadership & ,621 & ,648 & & ,537 & ,585 \\
\hline & Focus & 1,076 & ,369 & & 1,430 & 242 \\
\hline & Stuck in the middle & ,270 & ,897 & & 3,218 & $\underline{042}$ \\
\hline
\end{tabular}


In ANOVA analysis in table 6, the number of vehicles of the businesses was divided into 4 categories to be distributed as $20 \%$ and above. No difference at $p<0.05$ significance level has been found between stuck in the middle and the number of vehicles among the competition strategies. There is a difference at $p<0.05$ significance level between the competition strategies (differentiation, cost leadership and focusing) and the number of vehicles variable. There was no significant difference at $p>0.05$ significance level between competition strategies (differentiation, cost leadership, focus and stuck in the middle) and level of education variable. In other words, the practices of enterprises' competition strategies are independent of the level of education. In this case, the $\mathrm{H}_{5}$ hypothesis was completely rejected.

There was no significant difference at $p>0.05$ significance level between the competition strategies (differentiation, focus and stuck in the middle) and education area variable. There is a difference at $p<0.05$ significance level between stuck in the middle and education area variable in competition strategies. In other words, the managers that graduated from tourism, economy, business administration, automotive and other areas perceive only the strategy of stuck in the middle among the competition strategies in a different way while they perceive the others as the same. In this case, the H6 hypothesis is accepted for the stuck in the middle variable, while it is rejected for other variables. There was no significant difference at p>0.05 significance level between the competition strategies (differentiation, focus and stuck in the middle) and the duties of the senior, middle and first line managers working in car rental businesses. There is a difference at $p<0.05$ significance level between stuck in the middle and the duty of the manager variable in competition strategies. In other words, the managers perceive only the strategy of stuck in the middle among the competition strategies in a different way while they perceive the others as the same. In this case, the $\mathrm{H}_{7}$ hypothesis is accepted for the stuck in the middle variable, while it is rejected for other variables.

\section{CONCLUSION}

Today, globalizing market conditions and unlimited progress of production factors increase the importance of competition. Competition as a dynamic phenomenon rises as a precondition for continuing sales, profit or life, which is the aim of each business even though it depends on the environment and business type. Changes in globalization and developments in information technology all over the world affect the car rental industry as well as every sector. The majority of the participants of the research are male (90.5\%) and upper level managers (90.5\%). 57.5\% of the managers are married and $42.5 \%$ are single. Businesses mostly prefer both daily and operational renting (70.5\%) among market segments. It can be noted that Turkish car rental sector tends to provide services for the entire market. $38,5 \%$ of the managers have associate degree, $33,0 \%$ are high school graduates and $14,5 \%$ are undergraduates. In addition, the education level of the car rental business managers is high. In businesses, tourism graduates account for only $10.5 \%$. While the ratio of business graduates is $20,5 \%$, automotive $8,5 \%$, economy $7,5 \%$ and percentage of the individuals marking the option 'other' is $53 \%$. Other graduated fields are sociology, philosophy, history, geography, foreign trade, graphic design, computer, public administration, finance, public relations, construction-machinery and electronics engineering. Despite being a tourism activity, it is observed that the areas where the managers take education are different. It is noted that $21.5 \%$ (43) of the vehicle rental companies operating in istanbul and Antalya have between 3 and 17 vehicles, 26.5\% (53) have between 18 and 31 vehicles, $26.0 \%$ (52) have between 32 and 73 and $72 \%$ and $26 \%(52)$ have between 73 and 125 respectively. It is also observed that $49.5 \%$ (99) of these enterprises have $0-1$ branches and $50.5 \%$ (101) of them have 2-90 branches in terms of the number of branches. It can be inferred from these results that the car rental business in Turkey are of small and medium scale. The competition strategies preferred by the car rental businesses in istanbul and Ankara are respectively "differentiation", "cost leadership" and "focusing" and there are businesses that choose none of these strategies, "stuck in the middle". Difference analyses between managers' gender, marital status, mission, level of education, educational field, number of branches of the business, number of vehicles and their perception of competition strategies have been carried out and differences have been determined based on the competition strategies.

In Turkey, a total of 160.000 vehicles are used in the car rental sector, 30.000 of which are used daily (short-term) and 130.000 of which are corporate long-term corporate rentals. Car rental companies make 4.000 .000 daily rentals to 1.250.000 people per year (Turkey Hoteliers Federation, 2012: 19). Many multinational companies (Avis, Budget, Enterprise, Europcar, Sixty, Thrifty, Hertz, Leaseplan, Fleetcorp ect.) and local companies (Intersity rent a car, Derindere Filo Kiralama, Zeplin rent a car, GarentaDAY, Beyaz Filo Kiralama, Işıl Tur, Central rent a car, Lider Filo, Almira car rental service, Hedef Filo, Mengerler kiralama, Garanti Filo etc.) compete in Turkey.

The car rental sector in Turkey has indicated great improvement especially in recent years. Today, the fact that large and medium-sized businesses as well as small and medium-sized businesses shift towards renting instead of buying vehicles has increased the demand for renting operational vehicles. In addition, the increase in the number of airports, renting services being provided at sea and railway connection points and the increase in the number of tourists every year have increased the demand for daily rentals. 


\section{REFERENCES}

Altunışık, R., Coşkun, R., Bayraktaroğlu, S. \& Yıldırım, E. (2005). Sosyal Bilimlerde Araştırma Yöntemleri SPSS Uygulamalı, 4. Baskı, Sakarya Yayıncılık, Sakarya.

AUTO RENTAL NEWS (2016). Fact Book 2016, www.autorentalnews.com, Erişim Tarihi: 03.01.2017.

Bahar, Ozan \& Kozak, Metin (2012). Turizm Ve Rekabet, Detay Yay., Ankara.

Cronshaw, M., Davis, E. \& Kay, J. (1994). On being Stuck in the Middle or Good Food Cost Less at Sainsbur, Biritish Journal of Management, Vol:5, s.19-32.

DATAMONITOR (2011). Avis Budget Group Company Profile, www.datamonitor.com, Erişim: 01.01.2013.

Enright, M. J., \& Newton, J. (2004). Tourism destination competitiveness: A quantitative approach. Tourism Management, 25, 777-788.

Funk, V., Funk, K. W. \& Wind, J. Y. (2009). Düz Dünyada Rekabet, (Çeviri: Şensoy, Ü.), Optimist Yayıncılık, İstanbul.

García, M., Cortes, E., Marco-Lajara, B. \& Zaragoza-Sáez, P. (2014). Strategy, training and performance fit, International Journal of Hospitality Management, 42, 100-116.

Gençler, G. (2012). Beyaz Filo Oto Kiralama A.Ş. 01.01.2012-30.09.2012 Faaliyet Raporu, www.beyazfilo.com, Erişim Tarihi: 12.12.2012

Gezer, Ö. \& Çiçek, B. (2011). Binek Oto Kiralamalarında Vergi Uygulamaları, Mali Çözüm Dergisi, Sayı:11, Cilt:4, s:161-176.

Karaboğa, K. (2012). Araç Kiralama Sektörünün 1.6 Milyarlık Yatırımı, www.dunya.com/print.php?type, Erişim Tarihi: 12.02.2013.

Kesenci, Ç. A. (2010). Araç Kiralama Sektörünün Gelişimi Ve Ülke Ekonomilerine Etkileri, Tüm Oto Kiralama Kuruluşları Derneği (TOKKDER) Yayınları, İstanbul.

Kline, B. R. (2011). Principles and Pracitce of Structural Equation Modeling", 2th Edition, London, The Guilford Press.

Lo, Y. H. (2012). Back to Hotel Strategic Management 101: An examination of hotels' implementation of Porter's generic strategy in China, The Journal of International Management Studies, 7 (1), 56-69.

Mancini, M. (2012). Access: Introduction to Tourism and Travel, Wiley Publishing, USA.

Marijanovic, K. (2010). Differentiation of Car Rental Services in The Croatian Market, Preliminary Communication, Vol:XXII, s.113-128.

MARKET PUBLISHERS REPORT DATABASE (2012), The Car Rental Industry in Turkey: Market Entry Strategies and Emerging Opportunities, Analyses and Forecasts to 2016, http://www.autorentalnews.com, (Erişim Tarihi: 12.12.2012).

(MEB) Turkish Ministry of Education (2006). Konaklama ve Seyahat Hizmetleri Rezervasyon Sistemleri, Mesleki Eğitim ve Öğretim Sisteminin Güçlendirilmesi Projesi, Ankara.

Newton, S., Gilinsky, A. \& Jordan, D. (2015). Differentiation strategies and winery financial performance: An empirical investigation, Wine Economics and Policy, 4, 88-97.

Pachon, E. J. (2000). Strategic and Tactical Fleet Planning for the Car Rental Industry, Doctoral Theses, USA: University Of Miami.

Porter, M. (2000). Rekabet Stratejileri Sektör Ve Rakip Analizi Teknikleri, Çev. Ulubilgen, Gülen, Sistem Yayıncılık, İstanbul.

Taşkın, E., Kayabaşı, E. \& Kiracı, H. (2011). Rekabetçi yöntemlerin işletme performansı üzerinde etkisi: İnegöl'de Faaliyet Gösteren Ve İhracat Yapan İşletmeler Üzerine Bir Alan Araştırması, Pazarlama ve Pazarlama Araştırmaları Dergisi, Sayı: 08, 105-122.

Türkay, O. (2007). Pazara Dayalı Örgütsel Öğrenme: Konaklama İşletmelerinde Pazara Dayalı Örgütsel Öğrenmeyi Etkileyen Değişkenler Ve Pazarlama Performansına Etkileri, Doktora Tezi, Dokuz Eylül Üniversitesi, S.B.E, İzmir.

TURKEY HOTELIERS FEDERATION (2012). Turizm Raporu, TÜROFED Dergisi, Sayı:5.

Tyya, N. T. (2007). Hospitality \& Tourism Industry Employers, Vault Inc., USA.

Yang, Y., Jın, W. \& Hao, X. (2009). Dynamic Pool Segmentation Model and Algorithm in the Car Rental Industry, Journal Of Computers, Vol:4, No:12, s.1201-1210.

Yücenur, N., Demirel, Ç. N., Ceylan, C. \& Demirel, T. (2011). Hizmet Değerinin Müşterilerin Davranışsal Niyetleri Üzerindeki Etkisinin Yapısa Eşitlik Modeli İle Ölçülmesi, Doğuş Üniversitesi Dergisi, 12 (1), 156-168.

\section{Internet References}

http://www.turizmgazetesi.com/news.aspx?id=71446, Erişim Tarihi:20.10.2013. 